\title{
The Utilitarian Roles of Religion and Literature in Peaceful Co-Existence among Nigerians
}

\author{
Popoola S. Akorede and Unoroh Solomon Ogheneochuko \\ Michael Otedola College of Primary Education Noforija-Epe, Lagos State, Nigeria
}

\begin{abstract}
Religion and literature are disciplines that focus on man and his society. Both work to entreach acceptable ethical standards that enhance peaceful co-existence among people. This paper therefore explores the utilitarian roles of religion and literature in peaceful co-existence among Nigerians. From the review of related literature, Abdul, Sayyed, Ali, Adekunle etc are of the view that religion preaches and teaches peace [1] [3] [4] [8]. On the other hand, Wilson sees literature as an instrument of positive change [11]. Based on this, this research sets out to answer two questions on the utilitarian role of both religion and literature in enhancing peaceful co-existences among Nigerians. From the data collected, analyzed and discussed, it was discovered that both disciplines are veritable instruments that can be properly utilized to entreach peaceful co-existence among Nigerians.
\end{abstract}

\section{Introduction}

Religion and literature are agents of education. Both disciplines help people to see their roles or responsibilities in societal transformation. Also, religion and literature are socialization agents since they project the values and impact positive aspirations that will enhance peace and good neighborliness not only in the micro society but in the world generally. It is also important to note that man and religion are inseparable hence man is perceived as a religious being. This is because religion is an all-round movement in the light of faith in God and a sense of responsibility for the reformation of thought and belief. It aims to promote high principles of morality for the establishment of good relations among members of the society and the elimination of every sort of undue discrimination [12]. Religion encompasses the totality of man hence it is described as the opium of the people.

One of the basic teachings of all religion is peace. This can only be attained through a friendly, compassionate and co-operative attitude by all men. This is because, religion provides a sanction for the principles of morality like justice, honesty, righteousness, brotherhood, equality, virtuousness, tolerance, sacrifice, help to the needy and other kindred virtues. These are entrenched through doctrinal teachings by religious leaders. These values are the source sustaining humanity till today.

Nigerian Christians and Muslims cherish holiness and purity and transmit same to their offspring despite the current shift in national values from religious morality to material gains. This has helped in moral standards and family norms.

Despite the efforts of religious organizations to breed and bridge a peaceful society, some extremists attach to some objects an ultimate valuation and then attend to that over-valued object with what is recognizable as a kind of religious devotion. These attachments manifest in the form of spiritual needs that are consistent with their vision and how these can be satisfied through power and longings, Steffen [10]. When the desired needs become inconsistent with societal values, it results to conflict(s). Such disagreements mar peace and efforts are made to educate the masses through various mediums among which is literary expression.

Before delving into the role of literature in peaceful co-existence among Nigerians, it is imperative to note the views of religious experts on religion and peace.

\section{Religion and Peace}

Adesewo is of the view that religion is a form of belief system that supports healthful or positive psychological attitudes animal at societal peace [13]. It has to do with man's faith in power beyond him. Religion bounds individuals together into a value consensus. It powers the way for development of a collective conscience which is eternalized through collective rituals. Religion reinforces the society, promotes integration by ordering mechanisms for the achievement of consensus in the society.

Abdul pointed out that religion contains diverse elements - all bound together in a certain unity of outlook by the common belief in God or Allah [1]. According to him, religion means complete peace and submission onto the will of God. It is a complete way of life, and it is guided by politeness, neatness, good conduct etc. which are acceptable to everybody. On his part, Sayyed is of the view that in a Muslim society, relations must be friendly, compassionate and co-operative for mutual security and peace [8]. Sayyed further stated that where there is no security, there can be no peace. Corroborating 
the above view, Ali is of the opinion that Christians are to crave for peaceful co-existence at all times hence religious leaders should preach against all forms of insecurity [4] [8].

Commenting on "terrorism: The Position of Islam" - which constitutes insecurity - Adekunle pointed out that insecurity is totally rejected by Islam as it does not conform with Islamic ethics and injunctions in terms of behavioral pattern [3]. This is true because, Islam forbids injustice and enjoins moderation and justice even to an enemy.

From the Christian perspective, Christianity condemns war, violence and all forms of insecurity as morally unjustifiable. This is because violence, force, and threats are inconsistent with the ethics of Christ. Leith, Robertson and Jefferson are of the view that from the early church to the present day, espoused the pacific outlook as against any act that will ignite insecurity in the society [5] [6] [7].

\subsection{Religious Literature and Peaceful Co- Existence}

The main content of literature is human life. This is because, it is part of a people's cultural body that is both instructive and entertaining. It influences the society and drives it into different paths. Literary artists paint the ease and sorrows, smile and cry, joy and affection and vivid longings and prayers of mankind on the canvas of his literary creation. Through this, the social realities and the future of the society is brought to the reading public. According to Albert Camus in Jake, the aim of art, the aim of life can only be to increase the sum of freedom and responsibility to be found in every man in the world [14]. It cannot, under any circumstances, be to reduce or suppress that freedom, even temporarily. There are works of art that tend to make man conform and to convert him to some external rule. Others tend to subject him to whatever is worst in him, to terror or hatred. Such works are valueless to me.

The above is germane because, literature is a primary means of controlling and influencing human reasoning. It broadens and informs people of other truths in the pursuit of intellectual and societal perfection through contemplation that help in attending a stabilized society.

Wilson pointed out that religion and literature spring from the same fundamental sources and are formed by the same forces [11]. Both make constant appeal to life in relation to orderly use of reason; they accept the strength of human emotions, love, fear, curiosity, reverence and they both presume and accept the categorical imperative of the conscience and the freedom and force of the will of man. In addition, Shaw stressed that religion and literature gain dominance, prestige, and usefulness as they are the more intimately related to life [9]. It is based on these that literature is a veritable instrument in the sphere of education.

The choice of literary works as channel of education or a corrective instrument is based on the fact that religion and literature use similar methods and are indebted to each other. This is why great literary artists like Pope, Wordsworth, Browning, Tennyson, Achebe, Amadi, Ngugi, just to mention a few draw from religious issues with the intention of creating a better society where peace and tranquility will thrive best. It is this symbiotic relationship between religion and literature and their paramount place in achieving peaceful co-existence among Nigerians that this research work seeks to ascertain.

\section{Research Problem}

All over the word, religion occupies a paramount place in the lives of all human beings. This is because it is seen as a means to an end not only in this world but in the world to come. As a result, "believers" are taught to display the acceptable standard of behavior. Despite this, peaceful coexistence seems to be alluding humanity. In order to correct the anomalies, literature mirrors societal attitudes with the intention of correcting anti- social behaviors. This is why this research is aimed at reviewing the symbiotic influence of religion and literature in peaceful co-existence among Nigerians.

\subsection{Research Questions}

This research aims to find answers to the following questions:

i. Can religion fulfill its utilitarian rule of enhancing peaceful co- existence among Nigerians?

ii. What role can literature play in achieving peaceful co-existence among Nigerians?

\subsection{Methodology}

In order to ascertain the symbiotic influence of religion and literature as instruments of peace, this research applied two different sets of questionnaire: twenty questions demanding yes or no" responses on the role of religion and peaceful co-existence on fifty respondents and ten questions demanding "yes or no" responses on the functions of literature in attaining peace in the society to fifty respondents. The respondents were sampled randomly from 400 level students of Ekiti State University. The choice of the respondents was based on their level of education and reasoning faculty. The responses are calculated in simple percentage for the purpose of analysis and discussion. 


\section{Data Analysis and Discussion}

Table 1. The Place of religion in peaceful co- existence among Nigerians

\begin{tabular}{|c|c|c|c|c|c|}
\hline $\mathbf{S} / \mathbf{N}$ & QUESTION & YES & NO & \%YES & $\% \mathrm{NO}$ \\
\hline 1. & Do your religion preach peace? & 50 & - & 100 & - \\
\hline 2. & Is peace and religion related? & 26 & 24 & 52 & 48 \\
\hline 3. & Can religion give peace ? & 31 & 19 & 62 & 38 \\
\hline 4. & Do all religion preach or teach peace ? & 50 & - & 100 & - \\
\hline 5. & Can religion influence the level of peace in a society? & 32 & 18 & 62 & 38 \\
\hline 6. & Can religion be used as an instrument for peace? & 26 & 24 & 52 & 48 \\
\hline 7. & Should "believers" in your religion leave in peace with "non- believers"? & 50 & - & 100 & - \\
\hline 8. & Do the God you believe in encourage war against “unbelievers”? & - & 50 & - & 100 \\
\hline 9. & $\begin{array}{l}\text { Will those who have an indepth knowledge of your religion go against the } \\
\text { peace of the society? }\end{array}$ & - & 50 & - & 100 \\
\hline 10. & Can true religious leaders use others to disrupt the peace of the society? & 35 & 15 & 70 & 30 \\
\hline 11. & Does indoctrination help to disrupt peaceful co-existence in the society? & 50 & - & 100 & - \\
\hline 12. & Have you heard of religious crises? & 50 & - & 100 & - \\
\hline 13. & Have you experienced religious crises before? & 18 & 32 & 36 & 64 \\
\hline 14. & $\begin{array}{l}\text { Have you seen or heard of how lives and properties were destroyed because } \\
\text { of religious crises? }\end{array}$ & 50 & - & 100 & - \\
\hline 15. & Would you as an individual encourage religious crises? & 50 & - & 100 & - \\
\hline 16. & Should people of different religions live in crises? & - & 50 & - & 100 \\
\hline 17. & $\begin{array}{l}\text { Does breaching peaceful co- existence with unbelievers make one to spend } \\
\text { eternity in heaven? }\end{array}$ & - & 50 & - & 100 \\
\hline 18. & $\begin{array}{l}\text { Do you think educated people will directly be involved in going against } \\
\text { peaceful co- existence with "unbelievers"? }\end{array}$ & - & 50 & - & 100 \\
\hline 19. & $\begin{array}{l}\text { Do you live in harmony with members of your family that belong to other } \\
\text { religions? }\end{array}$ & 15 & 35 & 30 & 70 \\
\hline 20. & Will you encourage people to be religious? & 50 & - & 100 & - \\
\hline
\end{tabular}

One of the research questions that this paper intends to provide answer to is whether religion can fulfill its utilitarian role of enhancing peaceful coexistence among Nigerians. From the data gathered from the field survey, it was discovered that all the respondents agreed that all religions preach peace; $100 \%$ of the respondents encourage all to be religious while $52 \%$ are of the opinion that peace and religion are related. $62 \%$ of the respondents are of the view that religion can actually give peace since $62 \%$ attest to the fact that religion can influence the level of peace in the society.

Religion as a way of life ensures stability, positive change, unity, divine and human justice and gives hope to the downtrodden, the discouraged and the humble. This functional role of religion is recognized and valued in the society. As a result, religion can be used as an instrument of peace as indicated by $54 \%$ of the respondents. Also, because of the paramount place of religion in the society, $100 \%$ of the respondents agreed that all "believers" should embrace peaceful co-existence undermining individual belief system. This notion is as result of the fact that the God they believe in do not encourage war- as indicated through 100\% responses. To buttress this finding, Adebayo pointed out that the Nigerian constitution encourages freedom of religion and frowns at any conduct that can bridge peaceful co-existence among Nigerians [2].

Since peaceful co-existence can be realized through religion, why do we still witness religious conflicts in Nigerian? From the findings of this research, $100 \%$ of the respondents agreed of having heard of crises and expressed the view that an indepth knowledge of their religious belief will help greatly in achieving peace in the society. Though $36 \%$ of the respondents are yet to experience religious crises, $100 \%$ have heard of religious crises; $100 \%$ are also of the view that they will neither encourage crises nor encourage people of different religions to be involved in any form of crises since it is an anti-social behavior. This is because, $100 \%$ of the respondents agreed that crises is not a ticket to making it to eternity.

It must be noted that $100 \%$ of the respondents pin- pointed that the non-attainment of peaceful coexistence among Nigerians who believe in different religions is as a result of indoctrination. This is further indicated when $70 \%$ of the respondents indicated that religious leaders or teachers can use those who do not have an indebt knowledge of their 
religion and those who are not literate in the ideal sense to disrupt peaceful co-existence through fanaticism.

Table 2. The Role of literature in peaceful co- existence among Nigerians

\begin{tabular}{|l|l|l|l|l|c|}
\hline S/N & \multicolumn{1}{|c|}{ QUESTION } & YES & NO & \%YES & \%NO \\
\hline 1. & Do we have religion reflected in literature? & 50 & - & 100 & - \\
\hline 2. & Is there any relationship between religion and literature? & 45 & 05 & 90 & 10 \\
\hline 3. & Can literature be used to change one's orientation to life? & 32 & 18 & 64 & 36 \\
\hline 4. & Can literature be used to change people's religious life style? & 32 & 18 & 64 & 36 \\
\hline 5. & $\begin{array}{l}\text { Can literature be used as a medium to change people's attitude to } \\
\text { religious crises in the society? }\end{array}$ & 32 & 18 & 64 & 36 \\
\hline 6. & Can religious literature enhance peace and stability in the society? & 35 & 15 & 70 & 30 \\
\hline 7. & Can literature positively enhance one's belief system? & 32 & 18 & 64 & 36 \\
\hline 8. & Can literary works be used to cause religious crises in the society? & 40 & 10 & 80 & 20 \\
\hline 9. & $\begin{array}{l}\text { Can literature be used as an instrument to encourage peaceful co- } \\
\text { existence among people of different religions? }\end{array}$ & 37 & 13 & 74 & 26 \\
\hline 10. & Can literary artists use literature to teach religious doctrine? & 42 & 08 & 84 & 16 \\
\hline
\end{tabular}

The second research question to be attempted in this paper is the role of literature in achieving peaceful co-existence among Nigerians. First and foremost, it is an established fact that literature reflects life in a given society and part of what it mirrors is the religious atmosphere. This is attested to by respondents (100\%). Also, 90\% agreed that there is a relationship between religion and literature.

One of the functionalities of literature is that it is an instrument of social change. $64 \%$ of the respondents agreed that literature can change one's orientation to life; $64 \%$ also agreed that literature can change people's religious life style and attitude to religious crises in the society. The above dispositions are reflected in many literary works of Achebe, Amadi, Ngugi, Akachi, Adichiee.t.c. In the works of the above writers, the religious experiences of the people are reflected. In Achebe's Things Fall Apart, Arrow of God, Ngugi's The River Between, Adichie's Purple Hibiscus just to be mention but a few.

The above writers reflect religious conflicts in their novels. These crises are by-products of the over- zealous fanatical Africans whose understanding of their new found faith lacks the basic understanding of godly love. The religious leaders exploit their zeal for God to perpetuate evil in their own society by encouraging them to destroy the fabrics that bind the people together. The outcome is far from being desired. The lesson we must learn is that religion should not be used as an instrument of division and individual right to freedom of religion should be encouraged.

Literature has proven to be an effective medium of achieving change, stability, progress and even order in the society. This is supported by $70 \%$ and $64 \%$ respectively of the respondents who expressed the view that literature can enhance peace and stability in the society; and, that literature can enhance ones belief system. This is because writers express their opinions about their immediate societies. These opinions range from those seeking to point out certain practices that the artists think cannot produce growth and development of the society to those constituting outright protest against real and perceived enemies of the society.

It is based on the above that $80 \%$ of the respondents pointed out that literary works cannot be used to cause religious crises in the society instead, it is used as an instrument to encourage peaceful coexistence among people of different religion as testified by $74 \%$ of the respondents. This is true because, literature preaches and teaches moral presenting the good and bad aspects of the society and urging that the bad is eschewed and condemned. Furthermore, $84 \%$ of the respondents agreed that literary artists can use literature to teach religious doctrines that are in consonance with the acceptable norms of the society. This is due to the fact that literature as an art is used to ensure and aspire order in the society. As a result, the literary artist work, despite satisfying the entertainment need of the audience, must be functional, beneficial in such a way that proffers solutions to societies many problems including peaceful co-existence.

\section{Conclusion and Recommendations}

Peaceful co-existence is a product of a balanced, harmonious and understanding society underminding its pluralistic nature attainable through the symbiotic influence of both religion and literature. Both religious leaders and literary artists own their societies the obligation of using their positions to attain peaceful co-existence among the citizens. 
Secondly, government should bear in mind that ignorance is more expensive and disastrous compared to the cost and dividends of having "well educated citizens" that "cannot" be used as instrument of wanton destruction.

\section{References}

[1] Abdul, M.O.A (1988). The classical caliphate- Islamic institutions. Lagos Islamic Publication Bureau.

[2] Adebayo, R.I. (2003). Religion and National Unity in Journal of Religions and Cultural Studies vol.15, No2.

[3] Adekunle S. M. (2003). "Terrorism: The Position of Islam” in Apata C.T., Seriki I. A. and Arazi H.A

- Religion and Terrorism. NASRED .Ijebu-ode: Alamsek press limited.

[4] Ali, M. (1973).” Religions, Nations and The Search for a World Community - Christian- Muslim Dialogue.

[5] Jefferson, J.D (1993). Evangelical Ethics.Issues facing the church today. New Jessy: Presbyterian and reformed publishing company.

[6] Leith, J. (1970). Creeds of the Churches . N. Y: Yale University Press.

[7] Robertson M. (1977).” The Behavioural Sources under the Authority of Scripture " Journal of Evangelical Theological society.

[8] Sayyed, Q. (1977). Islam and Universal Peace.Idian: America Trust Publications.

[9] Shaw, C. G.(1984). Precinct of Religion in the culture and Humanity .N. Y. : Cambridge University press.

[10] Steffen C. (2007). Religions Fanaticism and Nation Building.NASRED Journal of Religions Studies. Vol .15 N0 2.

[11] Wilson, S. L. (1978). Theology of Modern Literature. N.Y: Cambridge University Press.

[12] Mutahhari et al (2003). Rationality of Islam. New York: Islamic seminary publications.

[13] Adesewo A. M (2007). The Scientific Exploration of Religion. Ilorin: Haytee Press and Publishing Co. Nig Ltd.

[14] Jake, W. (2009). http://open.salon.com /blog/ jakewilliams/ 2009/09/04

\section{Acknowledgement}

The authors acknowledge the authors whose works are cited in the reference section of this paper. Also, we appreciate the students of EKSU (Epe study Centre) who responded to the questionnaire that helped us to obtain the analyzed data. Thanks to Sunday and Kingsley Idogwu who helped to type the manuscript. 